\title{
Semantic Analysis of the Term Fitna in the Qur'an
}

\author{
Muhammad Hanif al Hakim ${ }^{1}$, Azhar Alam ${ }^{2}$ \\ Universitas Muhammadiyah Surakarta \\ 1'mha961@ums.ac.id, ${ }^{2}$ aa123@ums.ac.id
}

DOI: $10.29240 /$ alquds.v3i1.720

Submitted: 2019-02-04 |Revised: 2019-04-16 | Accepted: 2019-04-30

\begin{abstract}
Some Muslim groups often quote the Qur'anic verse Chapter Al-Baqarah 191 which shows the meaning of al-fitnatu asyadd min al-qatl. Based on that verse, they encourage every member of the Muslim community not to cast slander to other Muslims because slander is worse than killing. The meaning of the term 'slander' is still ambiguous and this article tries to explore its nuances. By using a qualitative approach and semantic analysis method, this study tries to describe various interpretations of slander from several prominent literary sources. This study aims to uncover the bulk of meanings of the word fitna as well to balance and to improve the narrow understanding of slander. This study found that the scope of meaning for the word fitna, includes words such as accusations, calamities, conflicts and disputes, which all have one purpose, i.e. efforts to find out which Muslims are good and which Muslims are bad. Fitna unexpectedly can befall us in various forms. Just like education tests, examinees or Muslims who are facing defamation must know how to overcome them.
\end{abstract}

Keywords: Meaning of fitna, Qur'an, Semantic Analysis, Hadith

\section{Introduction}

Muslim masses nowadays particularly those who are unlearned and gullible, oftentimes proclaim that when they are either gossiped or being accused of committing something bad, they get stuck in a statement called fitna. Thus they improperly quote Quranic verse which is to their understanding this verse gives them somewhat protection against it, usually the verse quoted in this case was verse 191 of Chapter Al-Baqarah which states al-fitnatu ashaddu min l-qatl. Based on that verse, they encourage each member of Muslim society not to throw fitna to other Muslim for fitna is worse than killing or in other word how can Muslim give his/her brother or sister fitna whereas killing itself is condemned in Islam. Apart from that, in this our own era which is obviously far from the time of Prophet Muhammad (Peace be upon him!) according to 
Prophetic Tradition narrated by Huzaifah b. al-Yaman, many fitnas appear in Muslim communities especially after the death of Caliph Omar. ${ }^{1}$ At a glance, in the light of two cases pertaining fitna above, fitna coaches kind of negative content. Yet what meaning it conveys still remains ambiguous and God willing that is what this article about to explore.

This study, which is qualitative in nature, utilizes descriptive analysis of the meaning of fitna from exegesis books. The semantic analysis in this study uses various interpretations of fitna terms from some Islamic scholars who define clearly of it. This study also explains the word fitna by another word, meaning and a linguistic form in one Ayab by means of another in another Ayah. To strengthen the analysis, this study also conducted literature review to get explanation of fitna meaning with the sunnah, statements of the Companions RA or Tabi'in, language, and lastly arguments based on opinion and deliberation (al-Ra'i wal-Ijtihad).

\section{The Semantics Usage In Exploring Fitna's Various Meaning}

In General, semantics refers to the philosophical and scientific study of meaning in natural and artificial languages. It is one of a group of English words formed from the various derivatives of the Greek verb sémainō ('to mean' of 'to signify'). The noun semantics and the adjective semantic are derived from sémantikos ('significant'). ${ }^{2}$ It is then the study of what a language uttered may mean. In other words, it can be said that a semantic theory should answer the question 'What is the meaning of this or that expression?'. ${ }^{3}$ In relation to the purpose of this article, semantics theory will be used to investigate fitna's meaning in the Quran.

The word fitna which frequenly occurs 34 times in the Quran, ${ }^{4}$ is noun form of verb fa-ta-na, which according to Lane in his monumental ArabicEnglish Lexicon, the verb its self has many signification. Some primary of them are to try, to afflict, and to distress; thus if the verb is converted noun form then

${ }^{1}$ Nu'aym b. Hammād, Kitāb Al-Fitan (Beirut: Dar al-Fikr, 1993), 22.. See also Șahīh Bukhārī no.1435. The prophetic tradition describes that there is a closed door, which protects Muslims society from fitna depicted as surging waves, between Caliph Omar and that fitna. Once the door is broken, it cannot be closed again to the Doomsday. Some asserts that Caliph Omar himself was the closed door.

2 Please see article 'Semantics' in Encyclopaedia Britannica website. "Semantics:

Definition \& Theories," Britannica.Com, accessed April 28, 2019, https://www.britannica.com/science/semantics.

3 Jeff Speaks, "Theories of Meaning," in The Stanford Encyclopedia of Philosopby (Winter 2018 Edition), ed. Edward N. Zalta, 2010, https://plato.stanford.edu/archives/win2018/entries/meaning/.

${ }^{4}$ Muhammad Fuad 'Abdul Baqî, Al-Mu'jam Al-Mufahras Li Alfaz̧h Al-Quran Al-Karim (Beirut: Dâr al-Kutub al-Misriyyah, 1364), 521. 
it turns into trial, affliction and distress; and it's meaning also posibly can be reduced to burn and burning. ${ }^{5}$ In addition, the definition offered by Lane matches with those suggested by Al-Jurjānī in his Ta'rifät as well as Al-Tahānawī in his Kasysyäf. They envisage the term as when someone melt the precious metal such as gold and silver with fire in order to separate or distinguish the bad from the good or to see what was its degree of goodness. ${ }^{6}$ Thus we derive other correlated significations from the key signification of trial, such as being tested or in a case where a student finding theirselves examined in order to get the higher grade; and afterwards the test result reveals and there appears who are passing and failed based on their values of assesment. The examinee who passes the test is the successful one, although he meets the minimum required standards to pass the test. He thus elevates his grade by which is reward for him whereas those who are failed remain in previous grade; and this is regarded as punishment they merit. Then occasionally the name of students coming out within the first-three rank of the top get special honor for their hard work and not for the fourth and so on. In this case, the trial or test obviously happens in educational life and perhaps the general insight of trial can be attained to bring our understanding to next elaboration word of fitna.

In previous paragraphs, I have briefly expounded the notion of test in academic realm as an introductory point. To put it in the religious context, however, it would not deviate much from its original meaning. The trial in the Quran thus means a test of the believer's faith, which for the man wedded to his desires, would have the appearance of an invitation to abandon the faith. ${ }^{7}$ In the Holy Quran there are many verses speaking of trial. ${ }^{8}$ One of the most salient verse is Chapter Al-Mulk verse two:

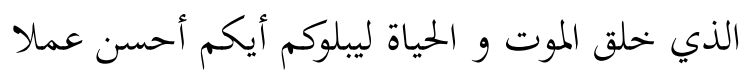

Who has created death and life that He may test you which of you is best in deed.

Although the verse in which contained word conveying the notion of trial or test is derived from triliteral root ba-la-ya instead of from fa-ta-na, both bear the same significance; and that is al-ikbtibär. ${ }^{9}$ As Al-Zabìdī quoted in his Täj

${ }^{5}$ Edward William Lane, Arabic-English Lexicon (Beirut: Riad el-Solh Square, 1968).

"Ali b. Muhammad Al-Jurjani, Mu'jam Al-Ta'rifat (Kairo: Dar Fadhilah, n.d.), 138. Cf alTahānawī, Mausūat Kashshäf Ishthilāhāt Al-Funūn Wa 'l-Ulüm (Beirut: Maktab Lubnān, 1996), 1264.

${ }^{7}$ B. Lewis, Ch. Pellat, and J. Schacht, eds., The Encyclopaedia of Isläm (Leiden: Brill, 1991), 2, 930 .

${ }^{8}$ See QS.29:1, QS.2:102, QS.20:85, QS.8:28, and QS.21.35.

${ }^{9}$ Al-Zabīì̄, Täj Al-'Arūs Min Jawāhir Al-Qāmūs (Kuwait, 2001), 37. 206. 
al-'Arüs the saying of Al-Azhariy pertaining to other significances of fitna, which are al-ibtilä $u$ and al-imtiban as well as al-ikbtibär. ${ }^{10}$ In fact, those three meanings possess the same essence after all which implies all information acquired after working with a set of test or trial. Here is Jalālain's interpretation of that verse:

...(He) Who created death, in this world, and life, in the Hereafter - or both of them in this world, since the sperm-drop is imbued with life, (life being) that (power) by which sensation becomes possible, death being the opposite of this or the nonexistence of it - these being two (alternative) opinions; in the case of the latter (life in the Hereafter), 'creation' implies 'ordainment' - that He may try you, that He may test you in (this) life, (to see) which of you is best in conduct...

Quoting the bolded part above "(to see) which of you is best in conduct", it implisitly inspires us of its opposite; and that is "which of you is worst in conduct". Likewise the treatment of teacher (as examiner) toward students in educational test (by providing reward and punishment according to their result), so do that of God upon His slave ('abd) in this dunya (worldly life). The expression 'best' denotes he (among Allah's slave) who mostly deserves the highest level of paradise similarly the 'worst' denotes those who merits the lowest level of paradise, if he could pass the test; otherwise the slave will enter the hellfire in case he failed it. Such this way, by setting this life as place of trials (dār al-imtihnañät $)^{12}$, Allah unveils the beliefers' faith degree. ${ }^{13}$

Such in this modern age if fitna was really intented either to distinguish the good from the evil or to proof the degree of faith on a man, it seems that there are numerous things whether are superficial or profound to some people which can be classified as that test. To better recognize what these things are, as a clue, Allah The Almighty has mentioned in the Holy Quran some of them.

First of all, the wealth and children as stated in The Holy Quran Chapter 64 verse 15 :

$$
\text { إنما أموالكم و أولادكم فنتة والله عنده أجر عظيم }
$$

Your riches and your cbildren may be but a trial: but in the Presence of Allah, is the highest, Reward.

${ }^{10}$ Ibid., 35. 492.

${ }^{11}$ Jalāl al-Dīn Muhammad ibn Ahmad Mahallī Suyuthi, Al-Qur' àn Al-Karìm: Bi Al-Rasm Al-Uthmāni. Wa Bihämishi Tafsìr Al-Imāmayn Al-Jalälayn (Beirut: Dar al-Ma'rifah, 1990).

${ }^{12}$ In his compilation of Quranic interpretation upon Chapter al-Kabf verse seven, Ibn Kathir mentions that Allah created this worldly life as immortal place embellished by transient endornment. Surely He created world as place of trials (där ikbtibäran) instead of decision place (där al-qarär).

${ }^{13}$ Chapter Al-An'ām verse 132. 
Also in previous verse the same chapter, Allah already warns the believers that their childrens and spouses may be their enemy. ${ }^{14}$ Pertaining these verses Ibn 'Abbas mentioned: "Some people used to receive Islam but, when trying to migrate, were restrained from doing so by their relatives and kinsmen. The latter would request to them, saying: 'We plead with you, by Allah, not to leave your kinsfolk and clan and leave for Medina where you do not have relations or fortune. Some of them felt sorry for their relatives and children and stayed back, thus failing to migrate, and so Allah, exalted is He, revealed this verse". ${ }^{15}$

Although the verse was pointed to some people in the time of Prophet Muhammad (peace be upon him) to be exact during hijrah eve, the message conveyed is still valid to be applied in the present context. Many muallaf converting to Islam face this kind of fitna and occasionally the people who was born to embrace Islam also experience the same fitna like that but in softer manner. For instance, a rich man with a nuclear family want to give charity (waqf or shadaqab) to ummah in quite remarkable amount. Thus his wife or at least through the mouth of mother in-law, persuades him not giving too much and even disposes better to spend the wealth all the way considering they both have worked hard for it. As the result the man cancelled the noble intention. In fact, if he remember that Allah will multiply what he loan to God, he would not take his wife's suggestion. ${ }^{16}$

In addition, the fitna of children, spouse and wealth were designed plainly not only for Prophet Muhammad (peace be upon him) and his ummah, but also for others Prophets (and their people) coming before him (peace be upon him). Some of them, as far as we know from Quranic verses, who were facing fitna of family are Prophet Noah and Prophet Luth (peace be upon them). ${ }^{17}$ Whereas those who were tested by overwhelming wealth is Qarun, one of Prophet Moses's people. ${ }^{18}$

Secondly, something of fear, hunger, loss of wealth, lives and fruits. ${ }^{19}$ Ibn Kathir reckons that Allah informs us that He tests and tries His servant, just as He said in another verse in QS.47:31:

${ }^{14}$ See QS.64:15.

15 'Alī b. Ahmad al-Wāhidī, Asbāb Al-Nuðūl, trans. Mokrane Guezzou (Jordan: Royal Aal al-Bayt, 2008).

${ }^{16}$ See QS.2:245.

${ }^{17}$ See QS.11:42-43, QS.66:10, QS.27:57 and QS.15:60.

${ }^{18}$ See QS.28:76-78.

${ }^{19}$ See QS.2:155. 


$$
\text { ولنبلونكم حتي نعلم المجهدين منكم و الصابرين و نبلو أخبركم }
$$

And surely, We shall try you till We test those who strive hard (for the cause of Allah) and Al-Säbirin (the patient), and We shall test your facts (i.e., the one who is a liar, and the one who is truthful).

Further he explains that 'something of fear and hunger' means a little of them; 'loss of wealth' means some of the possessions will be demolished; 'lives' means to lose comrades, families and loved ones to death; and 'fruits' means the yards and the plantations will not provide the regular or imagined amount. ${ }^{20}$ The god news is for Al-Säbirin (the patient) who when irritated by tribulation, assert: 'Truly, we belong to Allah and honestly, we will return to Allah' meaning, those who quote this statement to comfort themselves in the face of their loss, know that they belong to Allah and that He does what He wills with His servants. They know as well that nothing and no deed, even if it was the weight of an atom, will be lost with Allah on the Judgment Day. These facts thus oblige them to accept that they are Allah's servants and that their return will be to Him in the Hereafter. ${ }^{21}$ This is why Allah said in the next verse 157:

$$
\text { أولئك عليهم صلوت من ربهم ورمة و أولئك هم المهتدون }
$$

"They are those on whom are the Salawät (i.e., who are blessed and will be forgiven) from their Lord, and (they are those who) receive His mercy,)"

meaning, Allah's compliment and mercy will be with them. Sa'id bin Jubayr added, 'It means protection from the suffering.' "(and it is they who are the guided ones) are the height." "the heights means more reward, and these people will be awarded their rewards and more. ${ }^{22}$ It indicates that by gaining more reward the patients (al-Sabirün) will pay the high level of paradise with it. At this juncture, it can be said that this verse has corelation with previous verse two Chapter $\mathrm{Al}$ Mulk.

Thirdly, stuffs that might be fitna to Muslim are both the bounties of God given to us; thus we feel happy with it and affliction or hardship that can cause us feel in sorrow, as He, The Exalted says in the Holy Quran:

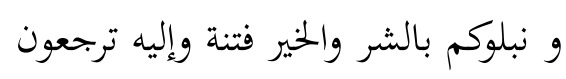

\footnotetext{
2002), 395.

${ }^{20} \mathrm{Abu}$ al-Fida `Ismail ibn Katsir, Tafsir Al-Qur'an Al-'Az̧bim (Kairo: Muassisât al-Mukhtâr,

${ }^{21}$ Ibid., 396.

22Ibid., 397.
} 
And We shall assess you with evil and with good by way of trial. And to Us you will be returned. ${ }^{23}$

Evil above as interpreted in Jalālain's means poverty and sickness while good means wealth and health. ${ }^{24}$ The same message was provided by Ibn Kathirr. However he explained that Allah tests His servants with prosperious sometimes and severity. ${ }^{25}$ It is no doubt, according to them the purpose of test is to show either the servant will thank (shakara) or expiate (kafara) on one hand if the fitna was the bounties. On the other hand, if the fitna was in evil form or calamity, it is to discover whether the servant will be patient (sabara) or in despair (qanata).

A careful reader may notice the strong connection between the two previous kind of fitna and the third, if he or she is full aware. The wealth, spouse and decendence in first example can be classified as fitna of bounties, while everything that can make people sad forms the fitna of severity. A Muslim might not mislead with both fitna as if Allah has honoured him by giving him honour and bounties and $\mathrm{He}$ has humiliated him if $\mathrm{He}$ tries him as Allah mentioned in The Holy Quran:

$$
\begin{aligned}
& \text { \#أما الإنسان إذا مابتله ربه فأكرمه ونعمه فيقول ربي أكرمن } \\
& \text { وأما إذا ماابتله فقدرعليه رزقه فيقول ربي أهنن }
\end{aligned}
$$

"And as for man, when his God afflicts bim, then treats him with honor and makes bim lead an easy life, he says: My God honors me. But when He tries him (differently), then straitens to him his means of subsistence, he says: My God has dishonoured me. ${ }^{, 26}$

The last thing considered as the highest level of fitna is apostasy of Islām (al-radd 'an'l-Islam) as a result of the non-believers' repellence toward Muslim from the way of God (sabilillah) according to many interpreters on Quranic verse:

And fitna is worse than killing. ${ }^{27}$

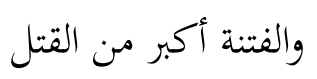

\section{And fitna is warse than killing.}

\footnotetext{
${ }^{23}$ See QS.21:35.

${ }^{24}$ Jalaluddin Al-Mahalli and Jalaluddin As-Suyuthi, Tafsìr Al Qur'an Al 'Azbim (Beirut: Dar al-Fikr, n.d.).

25ibn Katsir, Tafsir Al-Qur'an Al-'Azhim, 17, 449. In addition to that, 'Alī b. Abī Talḥah said that Ibn 'Abbas interpreted "nablükum" as a test of intensity (shiddah) and welfare (rakhä'un), of health (șịhah) and illness (saqam), of what is permissible (balāt) and illicit (baram), of

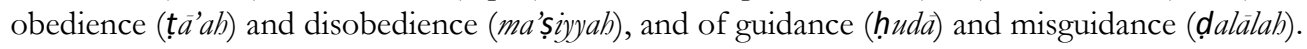
${ }^{26}$ QS.89:15-16.
} 
However, al-Rāzī inclined to support what was said by Muhammad b. Ishaq that fitna is whatever afflicts Muslim which is something to do with religion or faith matter. It can be by casting dubiosity in their heart sometimes, torturing them, such as what they had done to Bilāl b. Rabah, Șuhayb, and 'Ammār b. Yāsir. In other words, the word fitna to him conveys a sense of alimtihan. ${ }^{28}$ The rationality behind his argument is that persecute (fitna)which can weaken belief in someone will subsequently stir up massive murder on the face of earth and to worthiness of final sentenses in Hereafter. ${ }^{29}$ It is true thus to argue that the verse of 'fitna is worse than killing' was such an affirmation to the controvertial assassination that questioned by disbelifers afterwards, and that was the killing of Ibn al- Hadramiy. ${ }^{30}$

Apparently al-Rāzì's interpretation was the closest one to Prophetic Tradition mentioned on the face of this article, depicting perpetual rebellions which arose after the death of the second caliph, Omar b. Khațāab. Here is the full text of that Hadith:

Narrated Abu Wail:

Hudhaifa related, "Omar asserted, 'Who amongst you remembers the statement of the Prophet (peace be upon him) about tribulations?'

I replied, 'I know it as the Prophet had said it.'

'Umar Asserted, 'No doubt, you are bold. How did he say it?'

I replied, 'A man's afflictions (wrong deeds) concerning his spouse, progeny and communities are expiated by (bis) prayers, charity, and enjoining good.' (The sub-narrator Sulaiman added that he said, 'The prayer, charity, enjoining good and forbidding evil.')

'Omar said, 'I did not mean that, but I ask about that calamity which will disperse like the waves of the sea.'

${ }^{27}$ Fakhr Al-Dīn al-Rāzī, Mafätīh al-Ghaib known as al-Tafsìr al-Kabìr. QS.2:2017. Some of them who proposed that interpretation are Ibn Jarīr al-Tabarī and Ibn Katsīr.

${ }^{28}$ Ibid.

${ }^{29}$ Asbäb al-Nuzūl, 35. The reason why Allah revealed this verse is because they (Quraish clan) were still persecuting Muslimin in Allah's sacred precinct after believers had believed and this is greater in the sight of Allah than fighting the disbelievers during the sacred month while they still disbelieved in Allah. In addition to that, in his Mafätīh al-Ghaib al-Rāzī further expounded that if what is meant by fitna here was the action of infidel itself, then it overs only on individual responsibility in which he belongs to hellfire if he die disbelievingly. But if fitna was meant by conflict in society caused by the difference of believes or thoughts, then this will cause continuous chaos even murder.

${ }^{30} \mathrm{Mafätīh} \mathrm{al-Ghaib} \mathrm{known} \mathrm{as} \mathrm{al-Tafsir} \mathrm{al-Kabir.} \mathrm{The} \mathrm{message} \mathrm{there} \mathrm{was} \mathrm{to} \mathrm{abolish} \mathrm{one} \mathrm{group}$ or person who is able to rise conflict in a community is encouraged in order to maintain peaceful situation among them. 
I said, 'O chief of the believers! You do not need to be afraid of it as there is a closed door between you and it.'

He asked, 'Will the door be broken or opened?'

I replied, 'No, it will be broken.'

He said, 'Then, if it is broken, it will never be closed again?'

I replied, 'Yes.'

"Then we were afraid to ask what that door was, so we asked Masruq to inquire, and he asked Hudhaifa regarding it. Hudhaifa said, "The door was 'Omar.

"We further asked Hudhaifa whether 'Omar knew what that door meant. Hudhaifa replied in the affirmative and added, "He knew it as one knows that there will be a night before the tomorrow morning.",31

There are many Hadith telling of this kind of fitna besides that above. ${ }^{32}$ Hence the meaning of fitna is now becoming wider but is not diverging away from what have been determinated earlier, for the notion of fitna in this last category can be recognized if each member of society know well whether he stands on right or false group. So it aptly will be essentially a state of rebellion against the major group in which the minor always run the risk of being trapped. The idea which is to become dominant is that of "revolt", "disturbances", "civil war", but a civil war that breeds schism..$^{33}$ If so then it can be said that many fitna happened after the tenure of Caliph Omar. It can tell by some schisms appears either soon after during period of two succescor (Utsman and Ali) or years later within the collapse of Umayyad caliphate and so on. ${ }^{34}$

\section{Conclusion}

We have discussed so far things which can be regarded as fitna that might unexpectedly meet us. Likewise educational test, examinee have to know how to pass it successfully. Fortunately Allah have informed His servants that both shuker and sabr will help them facing it as has been explained by many distinguised interpreters above and Allah's Apostle Muhammad (peace be upon him) also confirmed that in his Prophetic Tradition. In addition, apart from

\footnotetext{
${ }^{31}$ Syihab al-Din Abu al-Fadhl Ahmad ibn Hajar al-'Asqalani, Fath Al-Bari Bi Syarh Shabih Al-Bukhariy (Beirut: Dar al-Fikr, 1996), 2, 11.

${ }^{32}$ Kitāb al-Fitan.

${ }^{33}$ Lewis, Pellat, and Schacht, The Encyclopaedia of Isläm, 2, 930.

${ }^{34}$ Ibid., 2, 931. Cf A.J. Wensinck, The Muslim Creed (New York: Barnes \& Noble, Inc, 1965), 109.
} 
shukr and sabr, knowledge is equally important as well, as mentioned in many Quranic verses and Prophetic Traditions. Provided when Muslim are well equipped with knowledge particularly that of their religion, they can distinct the good and the evil and that is whereby fitna wasset out.

\section{Bibliography}

'Abdul Baqî, Muhammad Fuad. Al-Mu'jam Al-Mufahras Li Alfaz̧h Al-Quran AlKarim. Beirut: Dâr al-Kutub al-Misriyyah, 1364.

Al-Jurjani, 'Ali b. Muhammad. Mu'jam Al-Ta'rifat. Kairo: Dar Fadhilah, n.d.

Al-Mahalli, Jalaluddin, and Jalaluddin As-Suyuthi. Tafsîr Al Qur'an Al 'Az̧̧im. Beirut: Dar al-Fikr, n.d.

al-Tahānawī. Mausū'at Kashshäf Ishthilāhät Al-Funūn Wa 'l'Ulüm. Beirut: Maktab Lubnān, 1996.

Al-Zabīiī. Täj Al-'Arūs Min Jawähir Al-Qàmūs. Kuwait, 2001.

'Asqalani, Syihab al-Din Abu al-Fadhl Ahmad ibn Hajar al-. Fath Al-Bari Bi Syarh Shabih Al-Bukhariy. Beirut: Dar al-Fikr, 1996.

Hammād, Nu'aym b. Kitāb Al-Fitan. Beirut: Dar al-Fikr, 1993.

Katsir, Abu al-Fida` Ismail ibn. Tafsir Al-Qur'an Al-'Azhim. Kairo: Muassisât alMukhtâr, 2002.

Lane, Edward William. Arabic-English Lexicon. Beirut: Riad el-Solh Square, 1968.

Lewis, B., Ch. Pellat, and J. Schacht, eds. The Encyclopaedia of Islam. Leiden: Brill, 1991.

"Semantics: Definition \& Theories." Britannica.Com. Accessed April 28, 2019. https://www.britannica.com/science/semantics.

Speaks, Jeff. "Theories of Meaning." In The Stanford Encyclopedia of Philosopby (Winter 2018 Edition), edited by Edward N. Zalta, 2010. https://plato.stanford.edu/archives/win2018/entries/meaning/.

Suyuthi, Jalāl al-Dīn Muhammad ibn Ahmad Mahallī. Al-Qur'àn Al-Karim: Bi AlRasm Al-Uthmāni. Wa Bihämishi Tafsìr Al-Imämayn Al-Jalälayn. Beirut: Dar al-Ma'rifah, 1990.

Wāhidī, 'Alī b. Ahmad al-. Asbāb Al-Nuəūll. Translated by Mokrane Guezzou. Jordan: Royal Aal al-Bayt, 2008.

Wensinck, Cf A.J. The Muslim Creed. New York: Barnes \& Noble, Inc, 1965. 